\title{
PENGARUH MENTAL WIRAUSAHA DAN KREATIVITAS TERHADAP MOTIVASI BERWIRAUSAHA PADA PENGUSAHA RUMAH MAKAN DI BEKASI
}

\author{
Oleh: \\ Eka Giovana Asti \\ Sekolah Tinggi Ilmu Ekonomi IPWI Jakarta \\ ekagiovanaasti@yahoo.co.id
}

\begin{abstract}
ABSTRAK
Usaha dalam bidang makanan saat ini telah menjadi trend, walaupun usaha ini memang butuh kerja keras dan usaha, dan bukan menjadi usaha yang asal-asalan. Namun telah banyak pengusaha yang sukses dalam menjalankan usaha di bidang ini. Guna menghadapi persaingan yang semakin ketat pada bisnis rumah makan, maka para Pengusaha rumah makan harus memiliki motivasi berwirausaha yang tangguh.

Penelitian ini akan mengganalisa dua faktor yang diduga akan dapat mempengaruhi motivasi berwirausaha, yaitu Mental Wirausaha dan Kreatifitas.

Peneliti menentukan sampel secara acak berjumlah 50 orang Pengusaha rumah makan di kelurahan Padurenan, Bekasi. Pengumpulan data menggunakan angket/kuesioner. Kategori jawaban responden penelitian terhadap angket terdiri atas lima skala berdasarkan skala Likert. Analisis data dilakukan dengan analisis regresi linier ganda.

Model penelitian Mental Wirausaha dan Kreativitas mampu menjelaskan 75,9\% variasi Motivasi Berwirausaha pada Pengusaha Rumah Makan di Kelurahan Padurenan, Bekasi. Mental Wirausaha dan Kreativitas terhadap Motivasi Berwirausaha pada Pengusaha Rumah Makan di Kelurahan Padurenan, Bekasi ditunjukkan oleh koefisien regresi dalam persamaan regresi $Y=5,271+0,907 X 1+1,288 X 2$.
\end{abstract}

Kata kunci:

Mental Wirausaha, Kreativitas dan Motivasi Berwirausaha

\section{PENDAHULUAN}

Di dalam berwirausaha mental juga sangat mendukung dalam keberhasilan. Menurut Bukhori (2001: 248) mental berwirausaha yaitu sikap seseorang dalam berperilaku, manusia yang bermental wirausaha mempunyai kemauan keras untuk mencapai tujuan dan kebutuhan hidupnya. Manusia yang bersikap mental wirausaha memiliki sifat kejujuran dan tanggung jawab.

Kewirausahaan yang biasa disebut juga wirausaha diyakini memberikan sejumlah manfaat, diantaranya adalah dapat memberikan kesejahteraan kepada masyarakat dengan jalan meningkatkan kemampuan wirausaha sendiri, memberikan banyak lowongan pekerjaan, menawarkan berbagai produk dan jasa 
kepada konsumen, dan pajak yang dibayarkan kepada pemerintah (Sisnuhadi dan Wijaya,2008). Maka dari itu penelitian mengenai kewirausahaan pun akan sangat berguna dalam rangka menambah minat masyarakat dalam berwirausaha yang pada gilirannya akan membantu program Pemerintah dalam meningkatkan penghasilan Pajak.

Menurut Penelitian Galih Noviantoro, (2017), terdapat hubungan positif dan signifikan antara Pengetahuan Kewirausahaan, Minat Berwirausaha, Dan Lingkungan Keluarga Terhadap Motivasi Berwirausaha. Begitu pula hasil penelitian Budi Azwar (2017) bahwa mental dan skap kewirausahaan akan mempengaruhi motivasi kewirausaan.

Penelitian ini akan menyoroti salah satu kegiatan wirausaha yaitu bisnis kuliner khususnya rumah makan yang menghadapi persaingan dari sesama rumah makan sejenis di lingkungan yang sama. Ada beberapa hal yang harus diperhatikan oleh para pengusaha rumah makan, diantaranya :

a. Pilihan menu makanan yang banyak diminati, dicari dan sesuai dengan cita rasa mayoritas konsumen.

b. Harus mengutamakan kualitas produk. Salah satu yang harus diperhatikan adalah bahan baku makanan da minuman, dan pada proses produksi harus menjaga kebersihan agar makanan dan minuman yag dihasilkan higinies, begitu pula untuk segi rasa harus pas, untuk itu pemberian bumbu harus sesuai.

c. Lokasi yang tepat, namun untuk pemula, demi menghemat biaya bisa membuka rumah makan di area depan rumah, atau di persimpangan jalan yaang banyak dilalui orang. d. Peralatan dan perlengkapan usaha harus sesuai dan sesederhana mungkin untuk para pemula.

e. Melakukan survey pasar untuk meneliti harga pasar, minat konsumen dan banyaknya pesaing.

f. Sumber daya manusia yang terlatih, jujur, dan disiplin.

Oleh karena itu mutlak diperlukan pengusaha rumah makan yang tangguh dengan memiliki motivasi berwirausaha yang optimal. Dalam penelitian ini akan dianalisa dua faktor yang diduga akan dapat memberikan pengaruh positif bagi peningkatan motivasi berwirausaha, yaitu mental wirausaha dan kreativitas khususnya pada pengusaha rumah makan di Kelurahan Padurenan, Bekasi.

\section{TUJUAN PENELITIAN}

Untuk menganalisis Pengaruh Mental Wirausaha Dan Kreativitas Terhadap Motivasi Berwirausaha Pada Pengusaha Rumah Makan Di Kelurahan Padurenan, Bekasi

\section{TELAAH LITERATUR DAN PENGEMBANGAN HIPOTESIS Mental Wirausaha}

Menurut Bukhori (2001: 248) mental berwirausaha yaitu sikap seseorang dalam berperilaku, manusia yang bermental wirausaha mempunyai kemauan keras untuk mencapai tujuan dan kebutuhan hidupnya. Manusia yang bersikap mental wirausaha memiliki sifat kejujuran dan tanggung jawab.

Mental merupakan kekuatan tekad dan keberanian dalam melakukan sesuatu secara bertanggung jawab. Wirausahawan harus memiliki mental unggul bukan mental standar atau mental asal-asalan, seperti asal ada, asal jadi, asal terjual, asal menjadi duit, dan seterusnya. Akan tetapi, 
wirausahawan harus memiliki mental unggul, seperti lebih baik, lebih bernilai, lebih berguna, lebih memudahkan, lebih lengkap, lebih berkualitas, dan seterusnya, seperti terdepan, terpandang, tersohor, dan terbaik.

Menurut Suryana. Yuyus, Bayu Katib (2001: 83) seorang pakar sumberdaya manusia, perilaku seseorang dibentuk oleh lingkungannya, baik itu lingkungan informal (keluarga), formal (sekolah), maupun non formalnya (organisasi sosial kemasyarakatan atau sejenisnya).

Berdasarkan pendapat di atas mental berwirausaha adalah sikap seseorang dalam berperilaku, seperti lebih baik, lebih bernilai, lebih berguna, lebih memudahkan, lebih lengkap, lebih berkualitas, dan seterusnya, seperti terdepan, terpandang, tersohor, dan terbaik.

\section{Kreativitas}

Terdapat banyak pengertian mengenai kreativitas, tetapi tidak ada satu pun definisi yang dapat diterima secara universal, sehingga pengertian kreativitas tergantung bagaimana orang mendefinisikan kreativitas itu sendiri.

Kreativitas didefinisikan tergantung dari orang memandangnya. Hal ini karena dua alasan, Pertama karena kreativitas "konstruk hipotetis" dan yang Kedua definisi kreativitas tergantung pada dasar teori yang menjadi acuan pembuat definisi. Rhodes (1961) menyebutnya “The Four P's of Creativity" (dalam Munandar, 2009) berdasarkan penekanannya definisi kreativitas dibedakan ke dalam empat dimensi, yaitu: Person (Pribadi), Process (Proses), Product (Produk) dan Press (Pendorong).

Selain itu definisi kreativitas juga dibedakan ke dalam definisi konsensual dan konseptual. Definisi konsensual menekankan segi produk kreatif yang dinilai derajat kreativitasnya oleh pengamat yang ahli. Bahwa suatu produk atau respons seseorang dikatakan kreatif apabila menurut penilaian orang yang ahli atau pengamat yang mempunyai kewenangan dalam bidang itu bahwa itu kreatif. Dengan demikian, kreativitas merupakan kualitas suatu produk atau respons yang dinilai kreatif oleh pengamat yang ahli.

Definisi konsensual didasari asumsiasumsi sebagai berikut: (a). Produk kreatif atau respons-respons yang dapat diamati merupakan manifestasi dari puncak kreativitas, (b). Kreativitas adalah sesuatu yang dapat dikenali oleh pengamat luar dan mereka dapat sepakat bahwa sesuatu itu adalah produk kreatif, (c). Kreativitas berbeda derajatnya, dan para pengamat dapat sampai pada kesepakatan bahwa suatu produk lebih kreatif dari pada yang lainnya. Definisi ini sering digunakan dalam bidang keilmuan dan kesenian, baik yang menyangkut produk, orang, proses maupun lingkungan tempat orang-orang kreatif mengembangkan kreativitasnya.

Definisi konseptual bertolak dari konsep tertentu tentang kreativitas yang dijabarkan ke dalam kriteria tentang apa yang disebut kreatif. Walaupun samasama menekankan pada produk, tetapi definisi ini tidak mengandalkan sematamata pada konsensus pengamat dalam menilai kreativitas, tetapi pada kriteria tertentu.

Menurut Amabile (dalam Dedi Supriadi, 2004) sesuatu produk dinilai kreatif apabila: (a). Produk tersebut bersifat baru, unik, berguna, benar, atau bernilai dilihat dari segi kebutuhan tertentu, (b). Lebih bersifat heuristik, yaitu menampilkan metode yang masih belum pernah atau jarang dilakukan oleh orang lain sebelumnya. Jadi definisi ini lebih didasarkan atas pertimbangan penilai yang biasanya lebih dari satu orang, dalam 
definisi ini pertimbangan subyektif sangat besar.

Rogers dalam Munandar (2009) menyatakan bahwa kreativitas adalah kecenderungan untuk mengaktualisasikan diri, mewujudkan potensi, dorongan untuk berkembang dan menjadi matang, serta untuk mengekspresikan dan mengaktifkan semua kemampuan organisme. Selanjutnya Munandar (2009) merumuskan kreativitas sebagai suatu proses yang memanifestasikan diri dalam kelancaran, kelenturan, dan keaslian dalam pemikiran. Kelancaran dalam arti mampu memberikan banyak gagasan dalam waktu terbatas. Kelenturan berarti mampu melihat berbagai macam kemungkinan penggunaan suatu benda, berbagai macam sudut pandang serta jawaban dari suatu masalah, serta Keaslian yang berarti mampu memberikan jawaban yang tak terduga, tidak terpikirkan oleh orang pada umumnya.

Menurut Satiadarma dan Waruwu (2003), Kreativitas pada dasarnya merupakan sesuatu yang baru, baik berupa gagasan maupun karya nyata, baik dalam bentuk ciri-ciri berpikir kreatif maupun berpikir afektif, baik dalam karya baru maupun kombinasi dengan hal-hal yang sudah ada.

Kreitner dan Kinicki (2005) menyebutkan bahwa Kreativitas merupakan proses menggunakan imajinasi dan keterampilan untuk mengembangkan produk, objek, proses atau pemikiran baru atau unik. Definisi ini menyoroti tiga jenis kreativitas. Pertama, seseorang dapat menciptakan sesuatu yang baru atau disebut juga sebagai kreasi; Kedua, seseorang dapat mengombinasikan atau menyintesiskan benda-benda (sintesis); dan yang Ketiga, seseorang dapat meningkatkan atau mengubah barangbarang yang dapat disebut sebagai modifikasi.
Berbagai definisi pada intinya memiliki persamaan, yaitu melihat kreativitas sebagai kemampuan seseorang untuk melahirkan sesuatu yang baru, baik berupa gagasan maupun karya nyata, yang relatif berbeda dengan apa yang telah ada sebelumnya. Kreativitas atau daya cipta juga memungkinkan munculnya penemuan-penemuan baru dalam bidang ilmu pengetahuan dan teknologi, serta dalam semua bidang usaha manusia lainnya.

Atas dasar teori dan studi tentang kreativitas, lahirlah enam asumsi terkait dengan kreativitas, yakni (Supriyadi, 2004):

1) Setiap orang memiliki kemampuan kreatif dengan tingkat yang berbedabeda. Tidak ada orang yang sama sekali tidak memiliki kreativitas, dan yang diperlukan adalah bagaimanakah mengembangkan kreativitas tersebut,

2) Kreativitas dinyatakan dalam bentuk produk-produk kreatif, baik berupa bentuk benda maupun gagasan (creative ideas),

3) Aktualisasi kreativitas merupakan hasil dari proses interaksi antara faktor-faktor psikologis dengan lingkungan,

4) Dalam diri seseorang dan lingkungannya terdapat faktor-faktor yang dapat menunjang atau justru menghambat perkembangan kreativitas,

5) Kreativitas seseorang tidak berlangsung dalam kevakuman, melainkan didahului oleh dan merupakan pengembangan dari hasilhasil kreativitas orang-orang yang berkarya sebelumnya, dan

6) Karya kreatif tidak lahir hanya karena kebetulan, melainkan melalui serangkaian proses kreatif yang 
menuntut kecakapan, keterampilan, dan motivasi yang kuat.

Kreativitas merupakan kemampuan mental dan berbagai jenis keterampilan khas manusia yang dapat melahirkan pengungkapan yang unik, berbeda, orisinal, sama sekali baru, indah, efisien, tepat sasaran dan tepat guna. Dalam manajemen, baik manajemen produksi, pemasaran, sumber daya manusia dan keuangan, kita selalu menerapkan suatu sistem yang hasil dan efisiensinya sudah teruji. Kreativitas terutama berperan dalam pengembangan produk baru, upaya pemasaran dan kegiatan Mental Wirausaha, pendidikan, pelatihan dan pengembangan Pegawai, situasi mendesak yang dihadapi Perusahaan, serta pelaksanaan dari sistem pengendalian mutu.

Berdasarkan analisis faktor yang dilakukan oleh Guilford dalam Supriyadi (2004) ditemukan adanya lima sifat yang menjadi ciri kemampuan berpikir kreatif, yaitu:

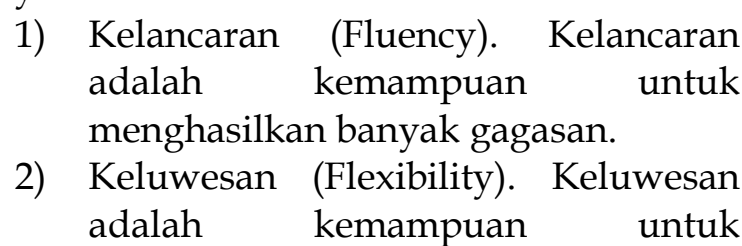
mengemukakan bermacam-macam pemecahan atau pendekatan terhadap masalah.

3) Orisinalitas (Originality). Orisinalitas adalah kemampuan untuk mencetuskan gagasan dengan caracara yang asli, tidak klise.

4) Elaborasi (Elaboration). Elaborasi adalah kemampuan untuk menguraikan sesuatu secara rinci.

5) Redefinisi (Redefinition). Redefinisi adalah kemampuan untuk meninjau suatu persoalan berdasarkan perspektif yang berbeda-beda dengan apa yang sudah diketahui oleh banyak orang.
Peluang untuk berkreasi adalah kesempatan seseorang untuk menciptakan sesuatu, sedangkan kreativitas adalah kemampuan seseorang untuk berpikir divergen dalam berbagai macam sudut pandang yang fleksibel dan bervariasi. Secara garis besar peluang untuk berkreasi dapat dilihat dari bagaimana proses kreativitas itu berlangsung.

Menurut Rhodes (dalam Munandar, 2009) kreativitas juga dapat ditinjau dari kondisi pribadi dan lingkungan yang mendorong individu berperilaku kreatif, sehingga Rhodes menyebut keempat dimensi kreativitas sebagai "Four P's of Creativity", yaitu Person, Process, Product, dan Press.

1) Pribadi (Person). Kreativitas sebagai ungkapan keunikan dari keseluruhan kepribadian, sebagai hasil interaksi individu dengan lingkungannya, dan yang tercermin dalam pikiran, sikap atau perilakunya. Kreativitas merupakan potensi (bakat) yang pada dasarnya dimiliki oleh setiap individu. Individu kreatif selalu ingin tahu, memiliki minat dan menyukai aktivitas yang kreatif. Biasanya mereka dapat melihat masalah dari berbagai sudut pandang dan memiliki kemampuan untuk bermain dengan ide, konsep atau kemungkinankemungkinan yang ada.

2) Proses (Process). Untuk mengembangkan kreativitas, seseorang perlu diberi kesempatan untuk mengekspresikan dirinya secara kreatif serta sarana prasarana yang memadai dalam kegiatan kreatif. Dalam hal ini yang penting adalah diperlukan waktu yang cukup, ketekunan, keuletan, dan kerja keras dari dalam diri individu.

3) Produk (Product). Produk kreatif dapat digolongkan menjadi tiga kategori, yaitu kebaruan, pemecahan, 
serta elaborasi dan sintesis. Kebaruan adalah sejauhmana produk itu baru dalam hal jumlah, teknik, bahan dan konsep yang terlibat. Pemecahan menyangkut sejauhmana produk itu memenuhi kebutuhan. Sedangkan elaborasi dan sintesis merujuk pada sejauhmana produk itu menggabungkan unsur-unsur yang tidak sama menjadi keseluruhan yang canggih. Produk kreatif sebagai hasil dari kualitas unik individu dalam berinteraksi dengan lingkungannya.

4) Pendorong (Press). Kreativitas dapat terwujud dengan adanya dorongan dalam diri individu (motivasi) maupun dorongan dari lingkungan. Penciptaan kondisi keamanan dan kebebasan dapat memupuk daya kreativitas individu. Kondisi keamanan dan kebebasan dalam arti bahwa menerima individu sebagaimana adanya dan memberi kepercayaan serta kebebasan untuk berekspresi.

Keempat dimensi kreativitas tersebut di atas saling berkaitan, yaitu Pribadi (Person) yang kreatif melibatkan diri dalam Proses (Process) kreatif, dan dengan dukungan atau dorongan (Press) dari lingkungan menghasilkan Produk (Product) yang kreatif.

Dari berbagai definisi yang diungkapkan oleh para ahli, dapat disimpulkan bahwa kreativitas adalah kemampuan yang dimiliki oleh setiap orang untuk dapat menghasilkan tindakan kreatif yang merupakan interaksi dari faktor Pribadi, Pendorong, Proses, dan Produk. Tindakan kreatif merupakan tindakan untuk menghasilkan sesuatu yang baru atau menemukan metode pemecahan masalah yang baru dengan mengkombinasikan antar unsur yang ada dan didasari oleh cara berpikir yang
Luwes, Lancar, Orisinil, Elaboratif dan Redefinisi.

\section{Motivasi Berwirausaha}

Ketika manusia akan melakukan suatu kegiatan akan dipengaruhi oleh suatu kondisi psikologis yang mendorongnya untuk melakukan kegiatan tersebut. Kondisi psikologis tersebut berasal dari dalam tubuh manusia dan memberikan dampak yang cukup besar terhadap keberhasilan dari suatu kegiatan. Kondisi psikologis atau dorongan tersebut dinamakan motivasi.

Menurut Suryana \& Bayu (2010: 98) motivasi berhubungan dengan dorongan atau kekuatan yang berada dalam diri manusia. Motivasi berada dalam diri manusia yang tidak terlihat dari luar. Sedangkan menurut Gerungan dalam Suryana \& Bayu (2010: 99) motivasi merupakan dorongan dalam diri manusia yang menyebabkan manusia tersebut melakukan sesuatu. Motivasi berwirausaha tidak dibawa sejak seseorang lahir, tetapi motivasi berwirausaha dapat dilatih, dipelajari dan dikembangkan. Motivasi berwirausaha merupakan suatu dorongan yang timbul dari diri seseorang untuk mengambil atau melakukan kegiatan yang berkaitan dengan bidang kewirausahaan.

Menurut Suryana \& Bayu (2010: 102117) motivasi memiliki tujuan untuk dapat menunjang karakteristik dari seorang wirausaha antara lain:

1) Pekerja Keras

Kerja keras merupakan modal dasar untuk keberhasilan seseorang (wirausahawan). Kerja keras atau etos kerja keras sering dianggap ebagai mimpi kuno dan seharusnya diganti, tetapi hardwork and smartwork tidak dapat dipisahkan lagi. Jadi selain kerja keras, efektif dalam bekerja 
merupakan 2 hal yang tidak dapat dipisahkan.

2) Tidak Pernah Menyerah

Dalam menjadi seorang wirausaha, tidak diperkenankan memiliki sifat yang mudah menyerah. Banyak wirausahawan yang telah berhasil dan sukses setelah wirausahawan tersebut melewati tantangan dan tetap berjuang untuk meraih kesukesan.

3) Memiliki Semangat

Seorang wirausahawan harus selalu gembira di dalam setiap situasi. Kegembiraan tersebut yang menjadi semangat untuk menjadi kekuatan. Dengan semangat dan kekuatan akan menumbuhkan keberanian yang akan mendukung keberhasilan.

4) Memiliki Komitmen

Komitmen merupakan proses pada individu untuk menyesuaikan dengan aturan, nilai dan tujuan dari perusahaan. Seorang wirausaha yang baik akan memiliki komitmen yang kuat untuk memberikan tenaga dan tanggung jawab yang dapat memajukan bisnisnya.

Faktor-faktor yang Mempengaruhi Motivasi Berwirausaha, Menurut Saiman (2009: 26) mengemukakan empat faktor motivasi seseorang untuk berwirausaha, yaitu sebagai berikut:

1) Laba

Dapat menentukan berapa laba yang dikehendaki, keuntungan yang diterima, dan berapa yang akan dibayarkan kepada pihak lain atau pegawainya.

2) Kebebasan

Bebas mengatur waktu, bebas dari supervisor, bebas dari aturan yang menekan, dan bebas dari budaya organisasi/perusahaan.

3) Impian Personal

Bebas mencapai standar hidup yang diharapkan, lepas dari rutinitas kerja yang berulang-ulang, karena harus mengikuti visi, misi, impian orang lain.

4) Kemandirian

Memiliki rasa bangga, karena dapat mandiri dalam segala hal, seperti permodalan, mandiri dalam pengelolaan atau manajemen, mandiri dalam pengawasan, serta menjadi manajer terhadap dirinya sendiri.

\section{Pengaruh Mental Wirausaha dan Kreativitas Terhadap Motivasi Berwirausaha}

Pada hakekatnya semua orang mutlak memiliki motivasi dalam berkerja, motivasi berprestasi merupakan daya pendorong untuk melakukan aktivitas dengan usaha aktif, sehingga memberikan hasil yang terbaik. Seseorang yang memiliki motivasi tinggi akan memikirkan disamping keberhasilan dalam mencapai tujuan juga memikirkan bagaimana cara memperolehnya dan faktor-faktor penghambatnya. Begitu pula untuk melakukan kegiatan berwirausaha, wirausaha merupakan orang yang jatuh cinta pada organisasinya dan akan melakukan segalanya untuk memperjuangkan dan menumbuhkan usahanya, akan lebih optimal dalam bekerja jika didorong oleh kondisi psikologisnya yang positif.

Dengan memiliki mental kewirausahaan, wirausahawan diharapkan akan bekerja lebih baik, lebih bernilai, lebih berguna, lebih memudahkan, lebih lengkap, lebih berkualitas, dan seterusnya, seperti terdepan, terpandang, tersohor, dan terbaik. Serta ditambah dengan memiliki kreativitas yang merupakan kemampuan seseorang untuk melahirkan sesuatu yang baru, baik berupa gagasan maupun karya nyata, yang relatif berbeda dengan apa yang telah ada sebelumnya, seorang 
pengusaha diharapkan akan lebih meningkat motivasi berwirausahanya.

\section{Kerangka Penelitian}

Dalam penelitian ini meliputi dua variabel bebas yaitu variabel X1 (Mental Wirausaha) dan variabel X2 (Kreativitas). Dan satu variabel terikat yaitu variabel $Y$ (Motivasi Berwirausaha). Model hubungan antara variabel bebas dengan variabel terikat dalam penelitian ini dapat dilihat pada gambar berikut:

Gambar 1

Kerangka Penelitian

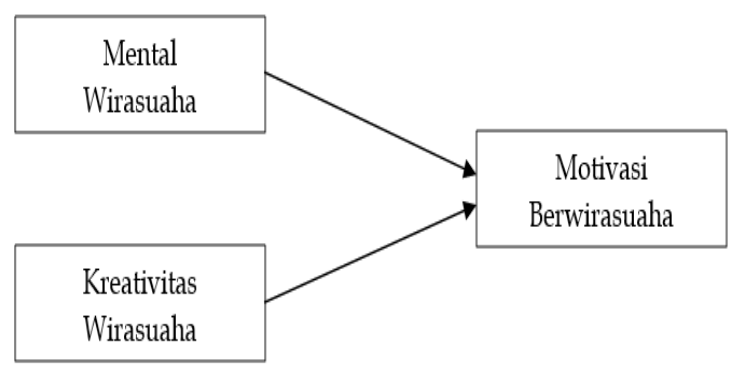

\section{METODE PENELITIAN \\ Jenis Penelitian}

Jenis dan rancang penelitian dapat dikelompokkan sesuai tujuan penelitian, pendekatan, tingkat eksplanasi dan jenis data. Penelitian ini tergolong penelitian asosiatif yaitu penelitian yang bersifat mencari hubungan atau pengaruh antara satu variabel dengan variabel lainnya.

\section{Lokasi dan Waktu Penelitian}

Lokasi yang dipilih sebagai tempat penelitian adalah Bekasi tepatnya di Kelurahan Padurenan, Bekasi. Waktu penelitian dilaksanakan pada bulan Oktober 2018.

\section{Populasi dan Sampel Penelitian}

Penentuan sumber data bergantung pada masalah yang akan diteliti, serta hipotesis yang akan diuji kebenarannya. Pada penelitian ini yang menjadi populasi penelitian adalah para Pengusaha Rumah Makan di Kelurahan Padurenan, Bekasi, khususnya rumah makan pribumi, seperti rumah makan Padang, rumah makan Tegal dan rumah makan Sunda yaitu sebanyak 50 orang Pengusaha Rumah makan.

Dikarenakan jumlah populasi adalah kurang dari 100, maka seluruh populasi dijadikan sebagai sampel penelitian. Jadi jumlah sampel (responden) dalam penelitian ini adalah sebanyak 50 orang Pengusaha Rumah Makan di Kelurahan Padurenan, Bekasi.

\section{Variabel Penelitian}

Dalam penelitian ini : Variabel bebas adalah Mental Wirausaha (X1) dan Kreativitas $(X 2)$. Variabel terikat adalah Motivasi Berwirausaha ( Y). Indikator Mental Wirausaha (X1) :

a) Percaya Diri

b) Berorientasi Pada Tugas dan Hasil

c) Berani Mengambil Resiko

d) Berjiwa Kepemimpinan

e) Berorientasi Ke Masa Depan

f) Keorisinilan Indikator Kreativitas (X2) :

a) Pribadi (Person).

b) Proses (Process).

c) Produk (Product).

d) Pendorong (Press).

Indikator Motivasi Berwirausaha $(\mathrm{Y})$ :

a) Laba

b) Kebebasan

c) Impian Personal

d) Kemandirian

\section{Pengumpulan dan Analisis Data}

Data diperoleh dari hasil daftar pertanyaan (kuisioner) yang telah dijawab dan diserahkan kembali oleh 50 responden sebagai sampel dalam penelitian ini.

Analisis Data Penelitian dilakukan dengan Analisis Regresi Linier Ganda. Persamaan regresi linier berganda (dua 
prediktor) yang digunakan adalah sebagai berikut: $\mathrm{Y}=\mathrm{a}+\mathrm{b} 1 \mathrm{X} 1+\mathrm{b} 2 \mathrm{X} 2$.

\section{HASIL DAN PEMBAHASAN}

Hasil analisis regresi linier ganda yang pertama adalah sebagai berikut:

Tabel 1

Model Summary

\begin{tabular}{|l|r|r|r|r|}
\hline Model & $\mathrm{R}$ & $\mathrm{R}$ Square & $\begin{array}{c}\text { Adjusted R } \\
\text { Square }\end{array}$ & $\begin{array}{c}\text { Std. Error of the } \\
\text { Estimate }\end{array}$ \\
\hline 1 & $.871^{\mathrm{a}}$ & .759 & .749 & 3.403 \\
\hline
\end{tabular}

a. Predictors: (Constant), Mental Wirausaha, Kreativitas

Sumber: Data diolah, 2018.

Berdasarkan tabel di atas ditemukan nilai R Square sebesar 0,759. Nilai tersebut menunjukkan bahwa model penelitian Mental Wirausaha dan Kreativitas mampu menjelaskan 75,9\% variasi Motivasi Berwirausaha di Pengusaha Rumah Makan di Kelurahan Padurenan, Bekasi.

Model persamaan regresi hasil penelitian diperoleh dari output analisis sebagai berikut:

Tabel 2

Koefisien

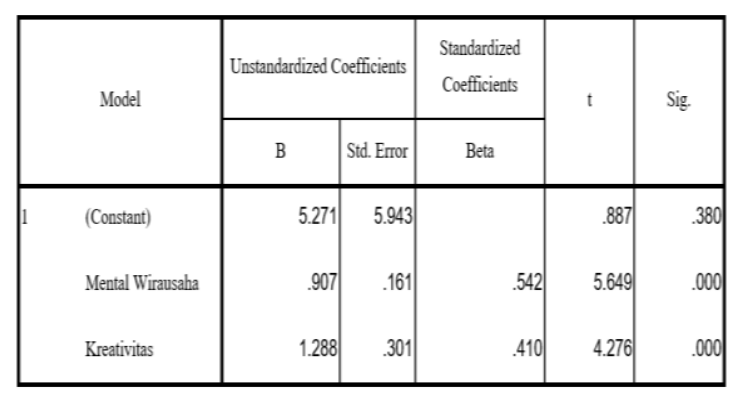

a. Dependent Variable: Motivasi Berwirausaha

Sumber : Data diolah, 2018.

Berdasarkan hasil analisa regresi di atas, maka dapat disusun persamaan regresi, yaitu: $Y=5,271+0,907 X 1+1,288$ $X 2$. Kemudian interpretasi dari persamaan tersebut adalah sebagai berikut:

1) Koefisien regresi (b1 =0,907), artinya jika Mental Wirausaha bertambah maka Motivasi Berwirausaha

Pengusaha Rumah Makan di

Kelurahan Padurenan, Bekasi akan bertambah.

2) Koefisien regresi (b2 $=1,288)$, artinya jika Kreativitas bertambah maka kualitas Motivasi Berwirausaha Pengusaha Rumah Makan di Kelurahan Padurenan, Bekasi akan bertambah.

\section{KESIMPULAN}

Penelitian menghasilkan model persamaan regresi linier ganda $Y=5,271+$ 0,907X1 + 1,288X2 dimana variable X1 (mental wirausaha) dan $\mathrm{X} 2$ (kreativitas) mampu menjelaskan $75,9 \%$ variasi $Y$ (motivasi berwirausaha).

1) Mental wirausaha berpengaruh terhadap motivasi berwirausaha dengan arah positif; semakin tinggi mental yang dimiliki akan meningkatkan motivasi berwirausaha Pengusaha Rumah Makan di Kelurahan Padurenan, Bekasi.

2) Kreativitas wirausaha berpengaruh terhadap motivasi berwirausaha dengan arah positif; semakin tinggi kreativitas yang dimiliki akan meningkatkan motivasi berwirausaha Pengusaha Rumah Makan di Kelurahan Padurenan, Bekasi..

\section{SARAN}

1) Pengusaha rumah makan harus memiliki mental unggul, seperti lebih baik, lebih bernilai, lebih berguna, lebih memudahkan, lebih lengkap, lebih berkualitas, dan seterusnya, seperti terdepan, terpandang, tersohor, dan terbaik.

2) Kreativitas harus ditingkatkan agar dapat melahirkan pengungkapan yang unik, berbeda, orisinal, sama 
sekali baru, indah, efisien, tepat sasaran dan tepat guna. Dalam manajemen, baik manajemen produksi, pemasaran, sumber daya manusia dan keuangan, kita selalu menerapkan suatu sistem yang hasil dan efisiensinya sudah teruji. Kreativitas terutama berperan dalam pengembangan produk baru, upaya pemasaran dan kegiatan Mental Wirausaha, pendidikan, pelatihan dan pengembangan Pegawai, situasi mendesak yang dihadapi Perusahaan, serta pelaksanaan dari sistem pengendalian mutu.

2) Penelitian ini dapat dijadikan rujukan untuk penelitian selanjutnya dengan responden dari wilayah lain, selain itu juga diperluas dan diperdalam lagi pembahasan mengenai variabelvariabel penelitian.

\section{DAFTAR PUSTAKA}

Alma, Bukhori, 2001, Kewirausahaan untuk Mahasiswa dan Umum, Alfabeta,.Bandung

Azwar, Budi, 2017, Analisis Faktor-faktor yang Mempengaruhi Kewirausahaan (Entrepreneurial Intention (Studi Terhadap Mahasiswa Universitas Islam Negeri SUSKA Riau), Riau

Handiprojo,Sukanto Resko, 2004, DasarDasar Manajemen, Badan
Penerbit Fakultas Ekonomi (BPFE), Yogyakarta

Munandar, Sukarni Catur Utami, 2009, Kreativitas dan Keberbakatan, Strategi Mewujudkan Potensi Kreatif dan Bakat, Gramedia Pustaka Utama, Jakarta

Noviantoro, Budi, 2017, Pengaruh Pengetahuan Kewirausahaan, Minat Berwirausaha, Dan Lingkungan Keluarga Terhadap Motivasi Berwirausaha Pada Mahasiswa Akuntansi Fakultas Ekonomi Universitas Negeri Yogyakarta, Yogyakarta

Robbins, Stephen P, 2003, Organization Behavior 9th Edition (Perilaku Organisasi, Edisi ke-9), Edisi Indonesia, Indeks, Kelompok Gramedia, Jakarta

Saiman, L, 2009, Kewirausahaan, Teori, Praktik, dan Kasus-kasus, Salemba Empat, Jakarta:

Suryana, 2001, Yuyus dan Bayu Kartib, Kewirausahaan: Pendekatan Karakteristik Wirausahawan Sukses, Kencana Prenada Media Group, Jakarta

Supriadi, Dedi, 2004, Kreativitas, Kebudayaan, dan Perkembangan IPTEK, Alphabeta, Bandung, 